\title{
NGRIP ice core reveals detailed climatic history 123 kyrs back in time
}

\author{
DoRThe DahL-Jensen
}

Niels Bohr Institute, University of Copenhagen, Denmark; ddj@gfy.ku.dk

\section{Introduction}

In 2003, for the first time, an undisturbed Greenland ice core record reaching further back than the glacial period was completed. The 3090 $m$ long ice core from NGRIP, on the northern part of the Greenland Ice Sheet, contains layers of snowfall from the last 123,000 years. The annual layers close to the surface are $0.19 \mathrm{~m}$ thick, corresponding to the present accumulation rate (in ice equivalent) and the annual layers at the base are all around $1 \mathrm{~cm}$ thick. The basal annual layer thickness is so well preserved due to a basal melt of $7 \mathrm{~mm} / \mathrm{yr}$, reducing the thinning near the bed (Dahl-Jensen et al., 2003). This very high-resolution record contains $1490 \mathrm{~m}$ of ice from the present interglacial period (0-11,703 yr b2k (before AD 2000)), $1600 \mathrm{~m}$ of ice from the glacial period $(11,703-115,000 \mathrm{yr} b 2 \mathrm{k})$ and $90 \mathrm{~m}$ of ice from the last interglacial period, the Eemian climatic period (NGRIP members, 2004)

\section{The NGRIP isotope record}

The stable isotope record from the NGRIP ice core is measured in $5 \mathrm{~cm}$ resolution. Down to a depth of 2900 $\mathrm{m}$ (105 kyr b2k), the record shows the same general climatic features as observed in other Greenland ice cores, including the Younger Dryas, the Bølling Allerød and the 24 abrupt and climatic warm Dansgaard/Oeschger (DO) events during the glacial period (NGRIP members, 2004). Whereas NorthGRIP and GRIP have very similar $\delta^{18} \mathrm{O}$ levels during the Holocene, glacial isotopic levels in the NorthGRIP record are systematically depleted by $1-2 \%$. The magnitude of the difference appears to be related to the Northern Hemisphere climate curve, as represented by a smoothed version of the NorthGRIP record, such that colder conditions have larger differences. A spatial pattern of glacial climate over Greenland begins to unfold. Our best theory is that the air masses reaching the two sites during the glacial were from different sources. In response to the

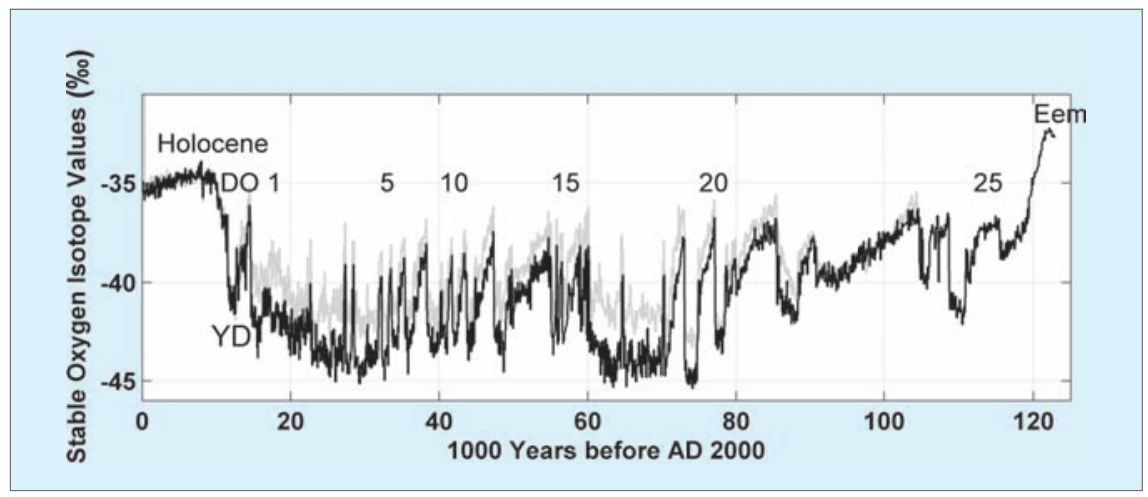

Fig. 1: The $\delta^{18} \mathrm{O}$ record from NGRIP (black) (NGRIP members, 2004) on the GICC05 timescale down to $2128.28 \mathrm{~m}$ (age 41,760 yr b2k) and below on a timescale based on a flow model that has been tuned to the GICCO5 timescale. The synchronized $\delta^{18} \mathrm{O}$ record from GRIP (gray) is shown down to 105,000 yr b2k so the two records can be compared. Some of the DansgaardOeschger warm stages (DO) are shown, and the Younger Dryas (YD), Holocene and Eemian climatic periods are marked.

extent of the Laurentide ice sheet, sea ice and the extensive North Atlantic ice shelves, NorthGRIP shows a more continental climate regime and may have seen a higher fraction of air coming over the northern side of the Laurentide ice sheet, bringing with it colder and more isotopically depleted moisture than GRIP might have seen. Taken as a whole, the findings here suggest that the atmospheric water cycle over Greenland is substantially different between modern and glacial worlds. The bottom $90 \mathrm{~m}$ of the NGRIP ice core contains ice from the last interglacial period. The isotopic value of this ice is high and corresponds to temperatures $5 \mathrm{~K}$ higher than the present. The part of the Eemian period from 123-115 kyr b2k found in the NGRIP ice core reveals that the period was warm and stable. The decline to glacial conditions happened slowly over 5000 years. It is interesting to note how soon the DO events begin to influence the climatic pattern. The first to be found at a depth of $3040 \mathrm{~m}$ (age 114 kyr b2k) might have happened before the full build up of the big glacial ice sheets was reached.

\section{Stratigraphic dating of the NGRIP ice core}

The very high resolution of the NGRIP ice core allows identification of the single annual layers down through large parts of the ice core. One of the goals of NGRIP has been to resolve these layers to gain understanding of the climate system and to produce a timescale based on counted annual layers. Chemical measurements using Continuous Flow Analysis (CFA), including dust and ECM on the melt water, visual stratigraphy (VS) and ECM on the frozen ice cores make it possible to resolve the annual layers down to 60 kyr b2k and perhaps further (Fischer et al., 2006; Rasmussen et al., 2005). The highly resolved records reveal that the abrupt climate changes like the warmings into DO events, the transition into the Bølling/Allerød and from the Younger Dryas into the Holocene happened over very short periods, sometimes only a few years. The highest resolution record is the visual stratigraphy with a resolution of $0.1 \mathrm{~mm}$ (Svenson et al., 2005). The annual layers can be seen here down to $100 \mathrm{kyr}$ b2k. The visual record also clearly demonstrates that the stratigraphy is preserved through the full NGRIP ice core.

A new Greenland Ice Core Chronology (GICC05) covering the last $41 \mathrm{kyr}$ has been constructed from stratigraphic annual layer counting of high-resolution records from the NGRIP ice core and from GRIP and Dye3 (Rasmussen, in press). Dating of the Holocene period back to the 8.2 kyr event is based partly on existing and partly on new stable isotope measurements of the Dye-3 (GISP1) ice core. For the interval 8.2-10 kyr 
b2k, the timescale has been obtained from Electrical Conductivity Measurements (ECM) of the solid ice and multiparameter chemical CFA of the GRIP ice core. Beyond $10 \mathrm{kyr} b 2 k$, the timescale is based on records from the NGRIP ice core: An extended spectrum of chemical paramaters using CFA, ECM, and the light intensity curve of the recorded VS. At any depth, the dating is based on the ice core with the best available high-resolution data, and the three ice cores are tied together using unambiguous reference horizons, such as volcanic ash layers or major acidity spikes. The maximum counting error at 41 kyr b2k is 1600 years. The new timescale places the Holocene/Pleistocene transition at $11,703 \mathrm{yr}$ b2k, the onset of Greenland Interstadial 3 (GIS3) at $27.8 \mathrm{kyr}$ b2k, and the onset of GIS8 at $38.3 \mathrm{kyr}$ b2k.

\section{Outlook}

At the base of the $3090 \mathrm{~m}$ thick ice sheet, the ice is melting and when bedrock was reached in 2003, basal water flooded the lowest $45 \mathrm{~m}$ of the borehole (Dahl-Jensen et al., 2003). The reddish refrozen basal water from the sub-glacial water system in the lowest $45 \mathrm{~m}$ of the borehole was recovered by drilling in 2004 and two macroscopic plant remains were recovered from the NGRIP core. One is a wood fragment of willow (Salix) and the other is a fragment of a bud scale, probably also from willow. Also, a few tiny fragments of spruce or larch (Picea/Larix) were found, potentially representing ancient vegetation from the time of

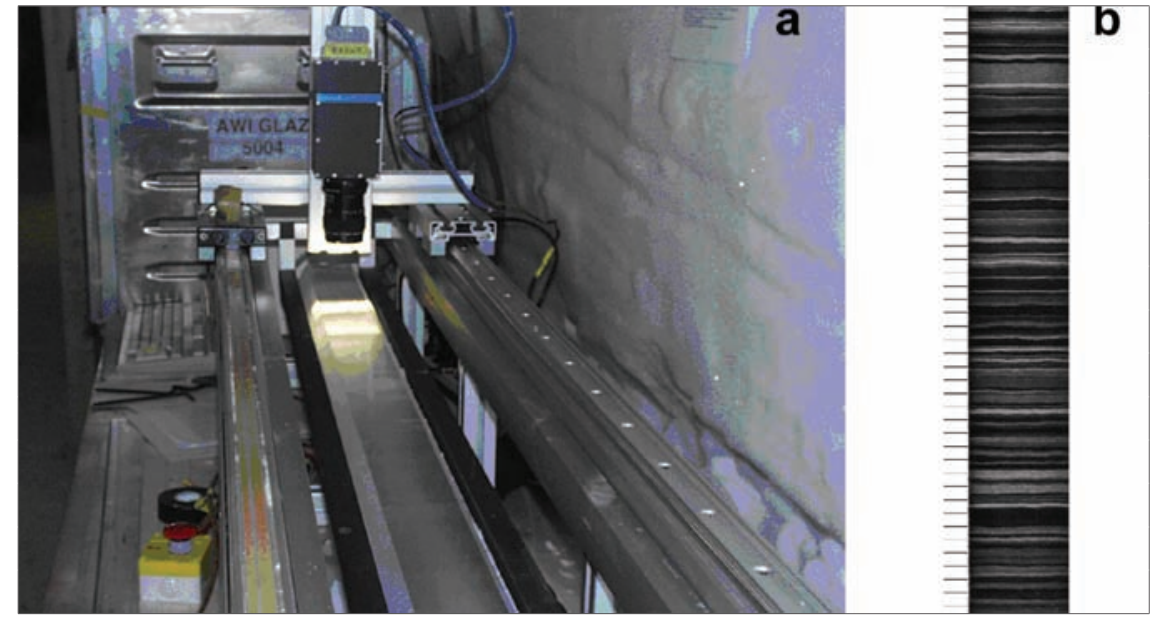

Fig. 2: As an example of the high-resolution data along the NGRIP ice core, data from the visual stratigraphy using the line scan instrument (a) is shown. A $50 \mathrm{~cm}$ long section of the record is shown in (b). The record is from $2358.0-2358.5 \mathrm{~m}$ where the age is $57 \mathrm{kyr} b 2 \mathrm{k}$ and the mean annual thickness is $1.2 \mathrm{~cm}$

the ice sheet formation. Many additional parameters like the gases, deuterium, deuterium excess, dust, as well as detailed comparisons with the Antarctic ice cores, are revealing

\section{Project facts}

Project: North Greenland Ice Core Project (NGRIP)

Contact: Dorthe Dahl Jensen, ddj@gfy.ku.dk

Participants: Numerous scientists from laboratories in 8 European nations and the USA.

Funding: Funding agencies in Denmark

(SNF), Belgium (FNRS-CFB), France (IPEV and INSU/CNRS), Germany (AWI), Iceland (Rannls), Japan (MEXT), Sweden (SPRS), Switzerland (SNF) and the USA (NSF, Office of Polar Programs)

Where: Northern Greenland

When: drilling 1996-2003, analysis ongoing.

What: $3090 \mathrm{~m}$ ice core from surface to bed-

rock, multiparameter analysis

Web page: www.glaciology.gfy.ku.dk/ngrip/ index_eng.htm

Database: www.glaciology.gfy.ku.dk/ngrip/ index_eng.htm outstanding results and will soon be published.

\section{REFERENCES}

Dahl-Jensen, D., Gundestrup, N., Gogineni, P. and Miller, H., 2003: Basal melt at NorthGRIP modeled from borehole, ice-core and radio-echo sounder observations. Annals of Glaciology, 37: 207-212.

Fischer, H., Siggard-Andersen, M.L. and Ruth U., submitted: Glacial/interglacial changes in mineral dust and sea salt records in polar ice cores: sources, transport, and deposition. Reviews of Geophysics.

North Greenland Ice-Core Project (NorthGRIP) Members, 2004: High resolution Climate Record of the Northern Hemisphere reaching into the last Glacial Interglacial Period. Nature, 431: 147-151.

Rasmussen, S. O., Andersen, K. K., Svensson, A. M., Steffensen, J. P., Vinther, B. M., Clausen, H. B., Andersen, M. -L., Johnsen, S. J., Larsen, L. B., Bigler, M., Röthlisberger, R., Fischer, H., Goto-Azuma, K., ice core chronology for the last glacial termination, Journal of geophysical research. in press.

Svensson, A., Wedel Nielsen, S., Kipfstuhl, S., Johnson, S.J., Peder Steffensden, J.P., Bigler, M., Ruth, U. and Röthlisberger, R., 2005: Visual stratigraphy of the North Greenland Ice Core Project (NorthGRIP) ice core during the last glacial period. Journal of Geophysical Research 110, D02108, doi:10.1029/ 2004JD005134. Hansson, M. E. and Ruth, U., 2005: A new Greenland

\section{Paleoenvironmental reconstruction from Alpine ice cores}

MARGIT ScHWIKoWSKI

Paul Scherrer Institute, Villigen, Switzerland; margit.schwikowski@psi.ch

\section{Introduction}

The European Alps, located in South-Central Europe, extend 800 $\mathrm{km}$ in the west-east and 150-200 $\mathrm{km}$ in the north-south direction (44$\left.48^{\circ} \mathrm{N}, 5.5-16^{\circ} \mathrm{E}\right)$. They form a great arc from the Riviera coast on the Mediterranean Sea, along the borders of northern Italy and adjacent regions of southeast France, Switzerland, southwest Germany and
Austria, into Slovenia. The total number of glaciers is 5422, covering an area of $3010 \mathrm{~km}^{2}$ (Paul et al., 2004). Glaciers with sufficiently cold firn temperatures, where melt-water percolation is negligible and which are therefore suitable for ice core studies, can be found above $4000 \mathrm{~m}$ asl in the northern part and above $4300 \mathrm{~m}$ asl in the southern part of the Alps (Suter et al., 2001). Thus, potential ice core sites are limited to a few high-elevation areas, such as the Bernese Alps, and the Monte Rosa and Mont Blanc areas.

The Alps are especially interesting for ice core studies because a dense network of instrumental meteorological measurements is available there and in the surrounding countries. The existence of such exclusive data sets is a ma- 